Article

\title{
Efficient Removal of Lead Ions from Water by a Low-Cost Alginate-Melamine Hybrid Sorbent
}

\author{
Keteng $\mathrm{Li}^{1}{ }^{1}$, Genhua Wu ${ }^{1, *}$, Min Wang ${ }^{1}$, Xiaohong Zhou ${ }^{1}$ and Zhuqing Wang ${ }^{1,2, *(D)}$ \\ 1 AnHui Provice Key Laboratory of Optoelectronic and Magnetism Functional Materials, \\ Anqing Normal University, Anqing 246011, China; donnelloirgt@gmail.com (K.L.); \\ wangmin08@aqnu.edu.cn (M.W.); wangzhq@aqnu.edu.cn (X.Z.) \\ 2 Faculty of Production Engineering, University of Bremen, Am Fallturm 1, D-28359 Bremen, Germany \\ * Correspondence: wugenh@aqnu.edu.cn (G.W.); wzhuqing@uni-bremen.de (Z.W.); \\ Tel.: +49-421-218-64581 (Z.W.)
}

Received: 27 July 2018; Accepted: 29 August 2018; Published: 1 September 2018

\begin{abstract}
A low-cost alginate-melamine hybrid sorbent (named as Alg-Mel) was designed and synthesized for the removal of $\mathrm{Pb}^{2+}$ from water. The as-prepared Alg-Mel sorbent exhibited high affinity and selectivity to $\mathrm{Pb}^{2+}$. The selectivity coefficients of the Alg-Mel for $\mathrm{Pb}^{2+} / \mathrm{Cd}^{2+}, \mathrm{Pb}^{2+} / \mathrm{Cu}^{2+}$, $\mathrm{Pb}^{2+} / \mathrm{Cr}^{3+}$ and $\mathrm{Pb}^{2+} / \mathrm{Co}^{2+}$ were all over 7. It is found that the hybrid sorbent could uptake $95.4 \%$ of $\mathrm{Pb}^{2+}$ from $\mathrm{Pb}^{2+}$-containing solutions $(0.48 \mathrm{mM})$, and the maximum adsorption capacity for $\mathrm{Pb}^{2+}$ reaches $1.39 \mathrm{mmol} / \mathrm{g}(287.7 \mathrm{mg} / \mathrm{g})$, which is much higher than that of most reported lead ion-sorbents. Furthermore, the Alg-Mel can be regenerated by a simple acid-washing process and used repeatedly. The results of adsorption mechanism analysis reveal that the adsorption of $\mathrm{Pb}^{2+}$ by Alg-Mel is mainly ascribed to the chemical coordination and ion exchange effects.
\end{abstract}

Keywords: adsorption; alginate; adsorbent; lead ion; wastewater

\section{Introduction}

Lead is a non-essential element of the human body [1]. Lead that enters the human body through the food chain cannot be degraded, and also accumulates in the human body for a long time, thereby causing damage to the intestinal system and nervous system, resulting in a series of physiological diseases such as colic, headache, insomnia and convulsions. In addition, lead has greater impacts on children in their development period. Previous studies have indicated that children are 30 times more sensitive to lead ion than adults, and excessive lead can severely affect their ability to speak, to remember and to pay attention [2]. Therefore, it is important to study the removal of lead ions from water.

Currently, many methods such as ion exchange, chemical precipitation, electrochemistry, membrane filtration, adsorption and biochemical treatment (bio-adsorption, flocculation, microbial metabolism) have been employed for the removal of $\mathrm{Pb}^{2+}$ from wastewater [3-5]. Among these methods, the adsorption method has attracted greater attention due to its simple operation, large processing capacity, can be used repeatedly, and has low-concentration wastewater treatment efficiency $(\leq 10 \mathrm{mg} / \mathrm{L})$. The most widely used adsorbent at present is activated carbon. Activated carbon has high specific surface area and reaction activity, and therefore it can remove lead ions from water. However, the high-quality activated carbon has a high preparation cost and its regeneration process is cumbersome, which limit the large-scale production and applications of activated carbon.

Over the past decade, many low-cost lead ion adsorbents have been developed to replace activated carbon [6-8], such as clay minerals, zeolites, chitosan and its derivatives, industrial waste and so on. However, these adsorbents often have one or more of the following deficiencies in the application 
process, for example: (1) less binding sites (functional groups such as $-\mathrm{COOH},-\mathrm{NH}_{2},-\mathrm{OH},-\mathrm{COO}$, $-\mathrm{CHO}$, etc.) on the surface of adsorbent materials, and a longer time required for adsorption to reach equilibrium; (2) low adsorption capacity for $\mathrm{Pb}^{2+}$ ions due to a small specific surface area; (3) the adsorbent is a powder material and is not easy to recollect and recycle; (4) the stability is not high. The morphology and adsorption performance of adsorbent decrease rapidly after repeated use; (5) the preparation or modification process is more complicated, and organic solvents (such as toluene, ethanol, etc.) are usually used. To overcome these disadvantages of traditional adsorbents, the macroscopic porous monolithic adsorbents are highly desired.

In our previous study, we used biocompatible sodium alginate as a raw material to prepare a green and efficient calcium alginate aerogel (CAA) by a simple one-step gel method and vacuum freeze-drying technique [9]. The fabricated CAA sorbent could uptake $96.4 \%$ of lead ions from $\mathrm{Pb}^{2+}$-containing solutions $(1.5 \mathrm{nmol} / \mathrm{L})$. The maximum adsorption capacity for lead ions was $390.7 \mathrm{mg} / \mathrm{g}$. However, after repeated use, the adsorption performance and morphology of CAA changed greatly. In order to solve this problem, in this work, the chemically stable melamine is modified on the surface of CAA to improve the physical and chemical properties of the aerogel. In addition, to the best of our knowledge, there have been no reports on the adsorption $\mathrm{Of}^{2+}$ by combined melamine and sodium alginate. The physical and chemical properties (such as adsorption ability and capacity, selectivity, etc.) of the synthetic alginate-melamine hybrid sorbent (Alg-Mel) are also evaluated by scanning electron microscopy (SEM), infrared spectrometry and inductively coupled plasma-optical emission spectrometry (ICP-OES).

\section{Experiment}

\subsection{Materials}

Melamine, sodium alginate, inorganic acids, 2-morpholinoethanesulfonic acid (MES), $N$-(3-dimethylaminopropyl)- $N^{\prime}$-ethylcarbodiimide hydrochloride (EDC), metal nitrate, $\mathrm{N}$-hydroxysuccinimide (NHS) and other reagents were bought from Shanghai Aladdin Biochemical Technology Co., Ltd., Shanghai, China. All reagents are of analytical grade and used without further purification. All aqueous solutions were prepared with distilled water. The $\mathrm{pH}$ value of solutions is adjusted by $1.0 \mathrm{M} \mathrm{HNO}_{3}$ or $\mathrm{NaOH}$ solution.

The tap water samples were collected from the tap of the laboratory and used directly. The river water samples were taken from the Anqing section of Changjiang River using a clean glass bottle and were allowed to stand for $12 \mathrm{~h}$ to precipitate the sediment before use. Battery plant wastewater samples were collected from the wastewater pool of Anhui Xunqi Power Technology Co., Ltd. Anqing, China, and used directly.

\subsection{Instruments}

The digital photo of the Alg-Mel sorbent was taken by an iPhone 6S camera, and the morphology and surface structure of the Alg-Mel were recorded on a SEM (Hitachi S-4800, Tokyo, Japan). Infrared spectra of samples were obtained from an infrared spectrometer (Nicolet 6700, Waltham, MA, USA). The carbon, hydrogen and nitrogen content of the Alg-Mel was analyzed by an elemental analyzer (Perkin-Elmer 2400, Waltham, MA, USA). The metal ions concentration was measured by an ICP-OES (Perkin-Elmer Optima 8000, Waltham, MA, USA). Each solution sample was determined in parallel three times and then averaged. The $\mathrm{pH}$ value of solutions was measured by an acidity meter (Leici PHS-3E, Shanghai, China).

\subsection{Preparation of Alg-Mel Sorbent}

The preparation route of Alg-Mel is illustrated in Figure 1. First, $1.5 \mathrm{~g}$ of sodium alginate was weighed and dissolved in $100 \mathrm{~mL}$ of $\mathrm{pH} 5.5 \mathrm{MES}$ buffer solution. $0.15 \mathrm{~g}$ of EDC and $0.12 \mathrm{~g}$ of NHS were then added successively (EDC activates the carboxyl group, NHS acts as a shrinking agent in the 
reaction of carboxyl group and amino group). After stirring for $3 \mathrm{~h}, 0.5 \mathrm{~g}$ of melamine was added and stirred for another $12 \mathrm{~h}$ at room temperature. Then, the mixed solution was dropped into $1000 \mathrm{~mL}$ of $0.5 \mathrm{M}$ calcium nitrate solution by using a $10 \mathrm{~mL}$ syringe (when the mixed solution was in contact with the calcium nitrate solution, an oval-shaped hydrogel was formed immediately), and continue stirring $30 \mathrm{~min}$ after the completion of the dropping. The solid hydrogel was separated by a decantation method and washed three times with distilled water. Finally, the hydrogel was immersed in distilled water and placed into a vacuum freeze-drying instrument, and the final Alg-Mel aerogel sorbent was obtained after freezing the hydrogel for $3 \mathrm{~h}$ at $-15^{\circ} \mathrm{C}$ and drying under vacuum for $24 \mathrm{~h}$.

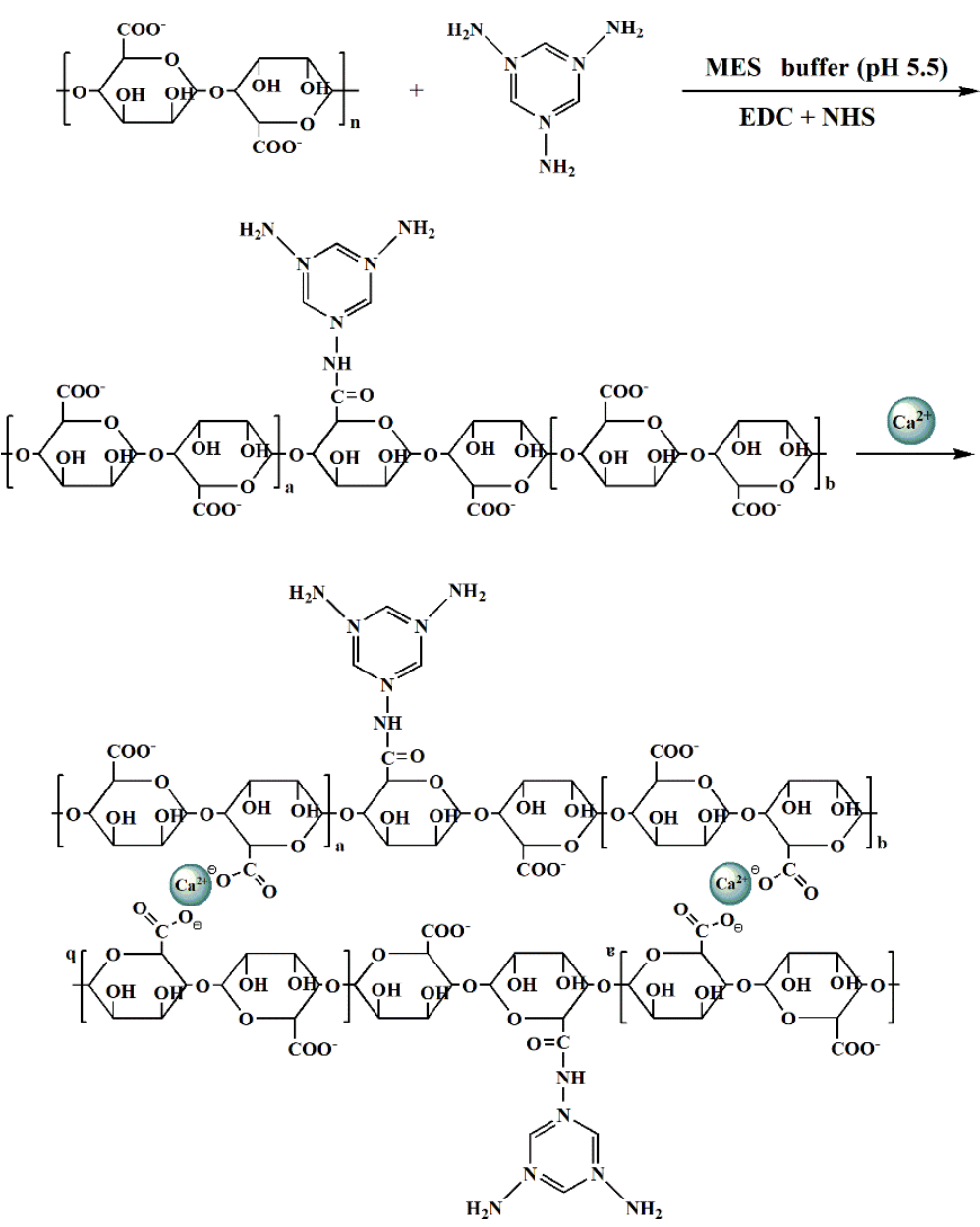

Figure 1. Preparation route of the Alg-Mel.

\subsection{Typical Adsorption Process and Desorption Process}

In the adsorption experiment, about $100 \mathrm{mg}$ (or $20 \mathrm{mg}$ ) of Alg-Mel sorbent was first weighed and added to $40 \mathrm{~mL}$ of $0.48 \mathrm{mM} \mathrm{Pb}^{2+}$ solution, stirred at room temperature for $6 \mathrm{~h}$, and then filtered. The amount of unextracted $\mathrm{Pb}^{2+}$ in the filtrate was measured by ICP-OES. The adsorption experiments of other metal ions were the same as above except that other metal ion solutions were used instead of the $\mathrm{Pb}^{2+}$ solution.

Desorption of $\mathrm{Pb}^{2+}$ was performed by mixing $\mathrm{Pb}^{2+}$-loaded Alg-Mel into $40 \mathrm{~mL}$ of $0.07 \mathrm{M}$ nitric acid solution for $1 \mathrm{~h}$. After that, Alg-Mel was separated by decantation and washed with distilled water for three times. The desorbed $\mathrm{Pb}^{2+}$ in the eluent was determined by ICP-OES.

In the regeneration experiment, the $\mathrm{Pb}^{2+}$-loaded Alg-Mel was first immersed into $40 \mathrm{~mL}$ of $0.07 \mathrm{M}$ nitric acid solution for $1 \mathrm{~h}$ at room temperature. Then, Alg-Mel was filtered and washed in sequence with distilled water, $0.001 \mathrm{M} \mathrm{Ca}(\mathrm{OH})_{2}$ solution and distilled water. 


\section{Results and Discussion}

\subsection{Material Characterization}

In order to confirm whether melamine and sodium alginate were successfully linked, we measured and compared the infrared spectra of sodium alginate, Alg-Mel hybrid and $\mathrm{Pb}^{2+}-\mathrm{loaded} \mathrm{Alg}-\mathrm{Mel}$. As can be seen in Figure 2, the broad adsorption peak at $3371 \mathrm{~cm}^{-1}$ belongs to the $v_{\mathrm{O}-\mathrm{H}}$ vibration. The weak adsorption peak at $2919 \mathrm{~cm}^{-1}$ was attributed to the aliphatic $\mathrm{C}-\mathrm{H}$ stretching vibration. The adsorption peaks at 1591 and $1329 \mathrm{~cm}^{-1}$ belong to $\mathrm{C}=\mathrm{O}$ and $\mathrm{C}-\mathrm{O}$, respectively [10,11]. When compared with the infrared spectrum of raw sodium alginate, there is a new adsorption peak of $\mathrm{N}-\mathrm{H}$ stretching vibration at $3217 \mathrm{~cm}^{-1}$ in the spectra of Alg-Mel and $\mathrm{Pb}^{2+}$-loaded Alg-Mel, which confirms that melamine was successfully linked with alginate. Moreover, after loading $\mathrm{Pb}^{2+}$, the $\mathrm{COO}^{-}$ (carboxylate) peak of the Alg-Mel shifted from 1329 to $1294 \mathrm{~cm}^{-1}$, which might be caused by the coordination of the carboxylate groups with the $\mathrm{Pb}^{2+}[12,13]$.

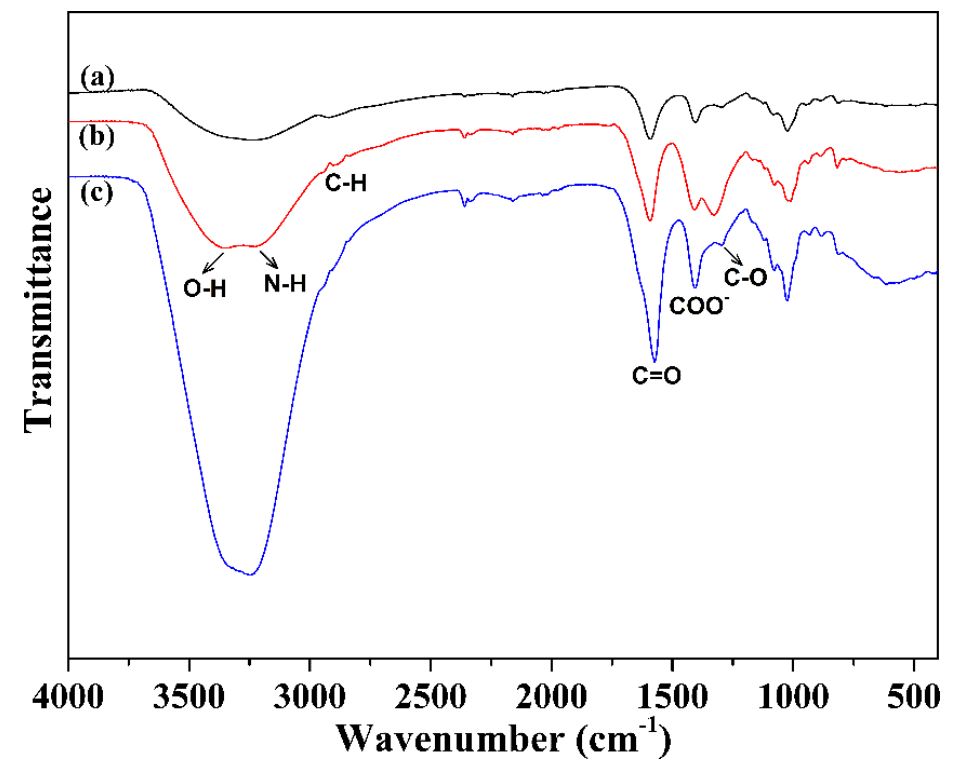

Figure 2. Infrared spectra of (a) raw sodium alginate, (b) Alg-Mel and (c) Alg-Mel loaded $\mathrm{Pb}^{2+}$.

Furthermore, the morphology of Alg-Mel was also characterized by SEM. As shown in Figure 3, the Alg-Mel is Oval-shaped and owns an uneven surface. On the other hand, the elemental analysis indicates that the mass percentage of carbon, nitrogen and hydrogen of Alg-Mel is 37.71\%, $14.76 \%$ and $3.93 \%$, respectively. It indirectly indicates that the Alg-Mel is rich in oxygen, and these oxygen-containing groups such as $-\mathrm{OH},-\mathrm{COO}^{-}$are beneficial in increasing the adsorption capacity of target metal ions.
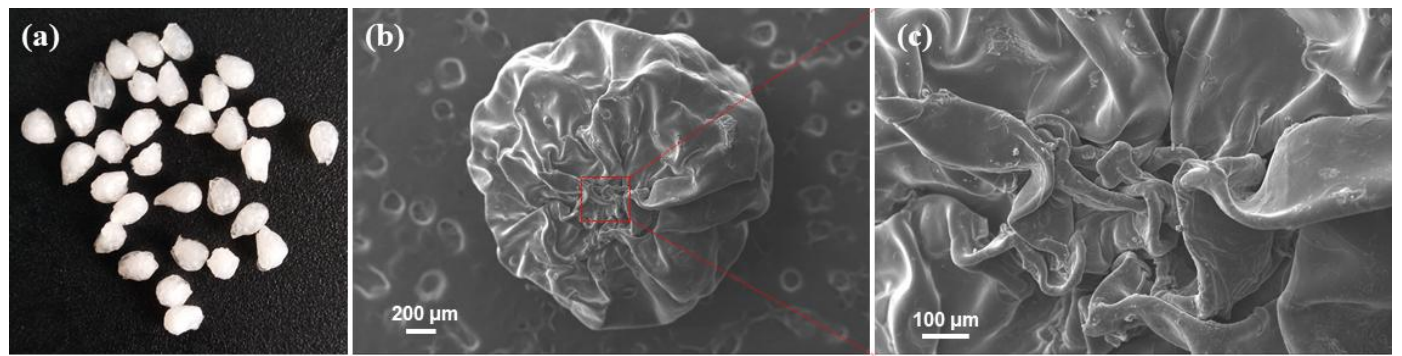

Figure 3. (a) Digital photo of Alg-Mel; (b) SEM image of Alg-Mel at low magnification; (c) SEM image of Alg-Mel at high magnification. 


\subsection{Influence of $p H$}

First, Alg-Mel sorbent (about $100 \mathrm{mg}$ ) was added into $40 \mathrm{~mL}$ of $0.48 \mathrm{mM}$ the $\mathrm{Pb}^{2+}$ solution with different $\mathrm{pH}$ values (range from 1 to 8 ), stirred at room temperature $\left(25^{\circ} \mathrm{C}\right)$ for $6 \mathrm{~h}$, filtered, and then the amount of unadsorbed $\mathrm{Pb}^{2+}$ in the filtrate was measured by ICP-OES. As shown in Figure 4, the influence of $\mathrm{pH}$ on the adsorption capacity of Alg-Mel can be divided into three stages: (1) when the $\mathrm{pH}$ value of the solution is less than 1 , the Alg-Mel can only adsorb less than $25 \%$ of $\mathrm{Pb}^{2+}$. This may be due to the $\mathrm{pH}$ value being lower than $\mathrm{pH}_{\mathrm{pzc}}$ (the $\mathrm{pH}_{\mathrm{pzc}}$ value of Alg-Mel is 1.83), the surface of Alg-Mel is positively charged and exhibits electrostatic repulsion towards $\mathrm{Pb}^{2+}$; (2) when the solution $\mathrm{pH}$ in the range of $1-5$, the adsorption capacity of Alg-Mel for $\mathrm{Pb}^{2+}$ increases rapidly with increasing of $\mathrm{pH}$. This can be ascribed to the negative surface charge (when the $\mathrm{pH}$ value is higher than $\mathrm{pH}_{\mathrm{pzc}}$ ) and strong chelating groups on the surface of the Alg-Mel; (3) when the solution $\mathrm{pH}$ is in the range of 5-8, the adsorption capacity of Alg-Mel remains stable. On another hand, according to the rule of solubility product, $\mathrm{Pb}^{2+}$ ions $(0.48 \mathrm{mM})$ will start to form $\mathrm{Pb}(\mathrm{OH})_{2}$ precipitation when the $\mathrm{pH}$ value of solution is greater than 5.74. Therefore, we suggest that the optimal adsorption condition for the Alg-Mel is the solution $\mathrm{pH}$ in the range of $5-5.74$. Within this range, neither the amino group is protonated nor $\mathrm{Pb}^{2+}$ ions are precipitated. Therefore, $\mathrm{pH} 5.0$ of the metal solution was chosen for the adsorption experiment in this study.

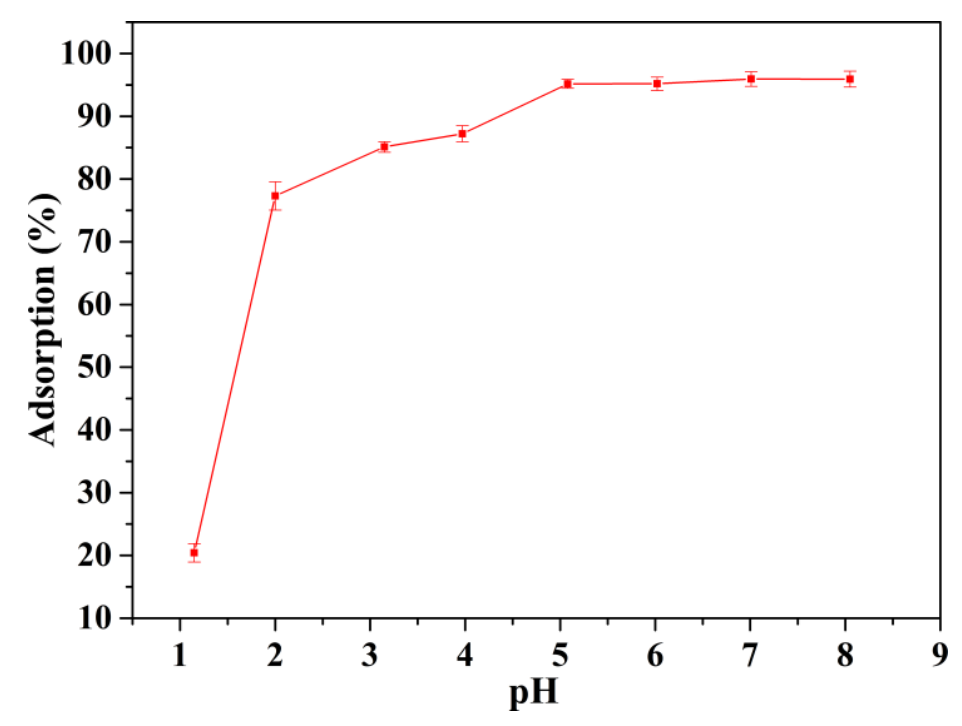

Figure 4. Effect of $\mathrm{pH}$ on $\mathrm{Pb}^{2+}$ adsorption of the Alg-Mel. ( 100 mg of Alg-Mel was equilibrated with $40 \mathrm{~mL}$ of $0.48 \mathrm{mM} \mathrm{Pb}^{2+}$ at $25^{\circ} \mathrm{C}$ for $6 \mathrm{~h}$ ).

\subsection{Effect of Contact Time and Temperature}

The effect of adsorption time on the adsorption capacity of Alg-Mel was also evaluated with contact time in the range of $0.5-12 \mathrm{~h}$ under $\mathrm{pH} 5.0$ at room temperature. It can be seen from Figure $5 \mathrm{a}$ that the adsorption capacity of the Alg-Mel for $\mathrm{Pb}^{2+}$ increases with the increasing of contact time and then remains stable. More than $95 \%$ of $\mathrm{Pb}^{2+}$ was adsorbed onto the Alg-Mel sorbent within $5 \mathrm{~h}$. On another hand, when $\sim 20 \mathrm{mg}$ of Alg-Mel was used for treating $40 \mathrm{~mL}$ of $0.48 \mathrm{mM} \mathrm{Pb}^{2+}$ solution, it took more than $12 \mathrm{~h}$ for the adsorption to reach equilibrium (Figure $5 \mathrm{~b}$ ). 


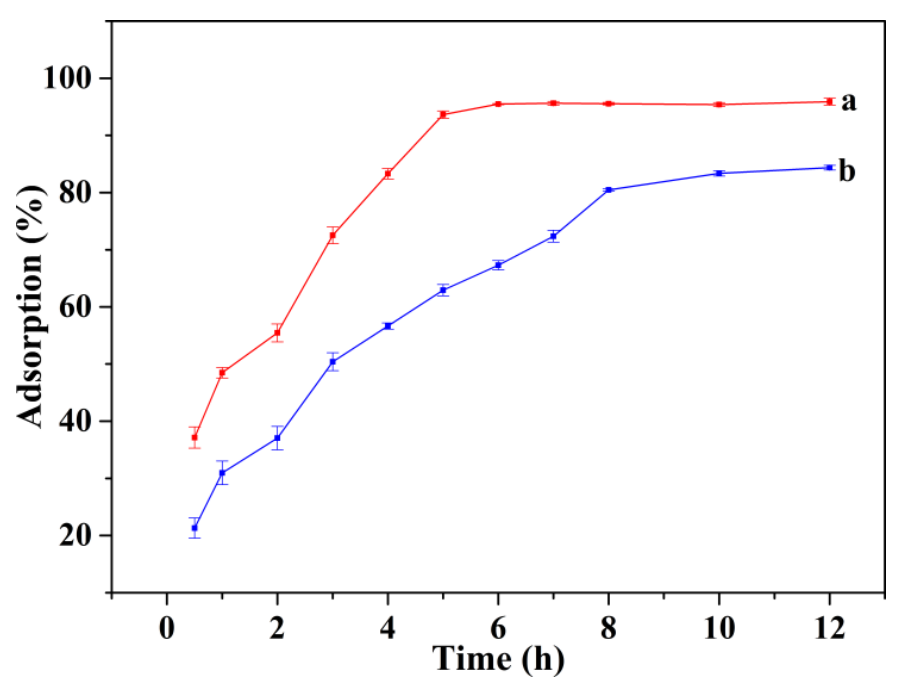

Figure 5. Effect of contact time on $\mathrm{Pb}^{2+}$ adsorption of the Alg-Mel. ( $\sim 100 \mathrm{mg}$ (a) and $\sim 20 \mathrm{mg}$ (b) of Alg-Mel was equilibrated with $40 \mathrm{~mL}$ of $0.48 \mathrm{mM} \mathrm{Pb}^{2+}$ at $\mathrm{pH} 5.0$ and $25^{\circ} \mathrm{C}$, respectively).

Furthermore, the influence of ambient temperature on adsorption abilities of the Alg-Mel was also studied. It can be seen from Figure 6 that the adsorption ability of the Alg-Mel for $\mathrm{Pb}^{2+}$ increases slowly with the ambient temperature rose from $20^{\circ} \mathrm{C}$ to $45^{\circ} \mathrm{C}$, which indicates that the adsorption process is an endothermic process.

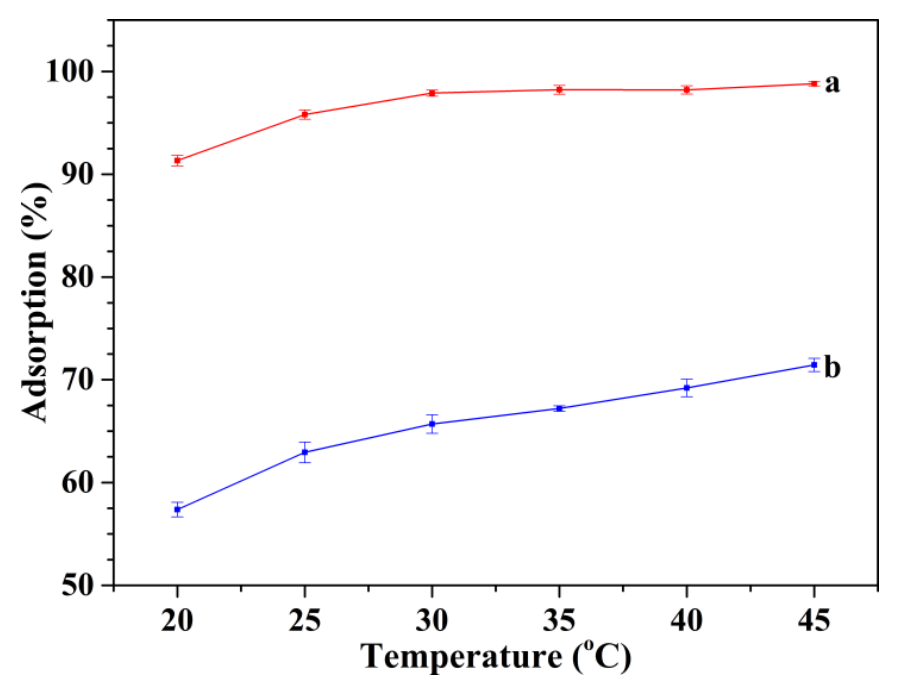

Figure 6. Effect of temperature on $\mathrm{Pb}^{2+}$ adsorption of the Alg-Mel. ( 100 mg (a) and $\sim 20 \mathrm{mg}$ (b) of Alg-Mel was equilibrated with $40 \mathrm{~mL}$ of $0.48 \mathrm{mM} \mathrm{Pb}^{2+}$ at $25^{\circ} \mathrm{C}$ and $\mathrm{pH} 5.0$ for $6 \mathrm{~h}$, respectively).

\subsection{Adsorption Ability and Selectivity}

The adsorption abilities of the Alg-Mel for heavy metals such as $\mathrm{Pb}^{2+}, \mathrm{Cd}^{2+}, \mathrm{Cu}^{2+}, \mathrm{Co}^{2+}$ and $\mathrm{Cr}^{3+}$ ions were also studied, and the results are listed in Table 1 (In an adsorption test, $100 \mathrm{mg}$ of Alg-Mel was equilibrated with $40 \mathrm{~mL}$ of metal ions-containing solution at $25^{\circ} \mathrm{C}$ for $6 \mathrm{~h}$, and then filtered. The unextracted metal ions in the filtrate was measured by ICP-OES). As can be seen in Table 1, the Alg-Mel sorbent shows high affinity to $\mathrm{Pb}^{2+}, \mathrm{Cd}^{2+}, \mathrm{Cu}^{2+}$ and $\mathrm{Cr}^{3+}$. It can uptake $95.4 \%$ of $\mathrm{Pb}^{2+}, 50.2 \%$ of $\mathrm{Cd}^{2+}, 59.3 \%$ of $\mathrm{Cu}^{2+}$ and $67.0 \%$ of $\mathrm{Cr}^{3+}$ from the corresponding solution, respectively. This may be ascribed to the coordination of the amino and carboxyl groups on the Alg-Mel with the heavy metals. Furthermore, the results of the competitive adsorption test indicate that the Alg-Mel 
sorbent has higher adsorption capacity and selectivity to $\mathrm{Pb}^{2+}$. The selectivity coefficient $(k)$ values for $\mathrm{Pb}^{2+} / \mathrm{Cd}^{2+}, \mathrm{Pb}^{2+} / \mathrm{Cu}^{2+}, \mathrm{Pb}^{2+} / \mathrm{Cr}^{3+}$, and $\mathrm{Pb}^{2+} / \mathrm{Co}^{2+}$ are all over 7 , which can be attributed to the similar hydrated radius of $\mathrm{Pb}^{2+}(0.40 \mathrm{~nm})$ and $\mathrm{Ca}^{2+}(0.41 \mathrm{~nm})$ and the higher binding energy of the carboxyl group with $\mathrm{Pb}^{2+}$ than other metal ions $[9,14]$.

Table 1. Adsorption abilities of Alg-Mel for various metal ions.

\begin{tabular}{|c|c|c|c|c|c|c|c|c|c|}
\hline \multirow{2}{*}{ Alg-Mel } & \multicolumn{2}{|c|}{ Initial Solution (mM) } & \multicolumn{2}{|c|}{ Adsorption (\%) } & \multicolumn{2}{|c|}{ Capacity (mmol/g) } & \multicolumn{2}{|c|}{$K_{d}$} & \multirow{2}{*}{$\begin{array}{l}k \\
-\end{array}$} \\
\hline & $0.48\left(\mathrm{~Pb}^{2+}\right)$ & - & 95.4 & - & 0.18 & - & 8.2 & - & \\
\hline \multirow{8}{*}{$\begin{array}{l}\text { Pure water } \\
\text { samples }\end{array}$} & $0.89\left(\mathrm{Cd}^{2+}\right)$ & - & 50.2 & - & 0.18 & - & 0.4 & - & - \\
\hline & $1.57\left(\mathrm{Cu}^{2+}\right)$ & - & 59.3 & - & 0.36 & - & 0.6 & - & - \\
\hline & $1.92\left(\mathrm{Cr}^{3+}\right)$ & - & 67.0 & - & 0.49 & - & 0.8 & - & - \\
\hline & $1.70\left(\mathrm{Co}^{2+}\right)$ & - & 29.1 & - & 0.19 & - & 0.2 & - & - \\
\hline & $0.48\left(\mathrm{~Pb}^{2+}\right)$ & $1.57\left(\mathrm{Cu}^{2+}\right)$ & 84.9 & 12.6 & 0.16 & 0.08 & 2.2 & 0.06 & 39.2 \\
\hline & $0.48\left(\mathrm{~Pb}^{2+}\right)$ & $0.89\left(\mathrm{Cd}^{2+}\right)$ & 82.4 & 37.7 & 0.16 & 0.13 & 1.8 & 0.24 & 7.7 \\
\hline & $0.48\left(\mathrm{~Pb}^{2+}\right)$ & $1.92\left(\mathrm{Cr}^{3+}\right)$ & 77.4 & 29.6 & 0.15 & 0.22 & 1.3 & 0.16 & 8.1 \\
\hline & $0.48\left(\mathrm{~Pb}^{2+}\right)$ & $1.70\left(\mathrm{Co}^{2+}\right)$ & 94.5 & 14.7 & 0.17 & 0.10 & 6.6 & 0.07 & 99.5 \\
\hline Tap water sample ${ }^{1}$ & $0.48\left(\mathrm{~Pb}^{2+}\right)$ & - & 94.1 & - & 0.17 & - & 6.0 & - & - \\
\hline River water sample & $0.48\left(\mathrm{~Pb}^{2+}\right)$ & - & 90.7 & - & 0.17 & - & 3.7 & - & - \\
\hline $\begin{array}{l}\text { Battery plant } \\
\text { wastewater }\end{array}$ & $0.08\left(\mathrm{~Pb}^{2+}\right)$ & $0.05\left(\mathrm{Cd}^{2+}\right)$ & 95.1 & 46.6 & 0.03 & 0.01 & 7.4 & 0.33 & 22.4 \\
\hline
\end{tabular}

${ }^{1}$ Tap and River water samples spiked with standard $\mathrm{Pb}^{2+}$.

The percentage of adsorbed metal ions (Adsorption\%), adsorption capacity (Capacity), selectivity coefficient $(k)$ and distribution coefficient $\left(K_{\mathrm{d}}\right)$ of Alg-Mel for $\mathrm{Pb}^{2+}$ were calculated as follows:

$$
\begin{gathered}
\text { Adsorption } \%=\frac{C_{i}-C_{f}}{C_{i}} \times 100 \% \text { Capacity }=\frac{\left(C_{i}-C_{f}\right) \times 0.04}{M W} \\
K_{d}=\frac{\left(C_{i}-C_{f}\right) \times 0.04}{C_{f} W} \quad k=\frac{K_{d}\left(P b^{2+}\right)}{K_{d}(\text { metal ion })}
\end{gathered}
$$

where $C_{i}$ represents the initial concentration of the metal ions in solution $(\mathrm{mM}), C_{f}$ represents the final concentration of the metal ions in solution $(\mathrm{mM})$. M represents the molar mass of metal ion, $W$ represents the mass of Alg-Mel sorbent $(\mathrm{g}) . K_{d}$ represents the distribution coefficient $(\mathrm{L} / \mathrm{g})$, and $k$ represents the selectivity coefficient.

\subsection{Maximum Adsorption Capacity for $\mathrm{Pb}^{2+}$}

The maximum adsorption capacity is the most important characteristic of a adsorbent, which determines the economics and practicability of the adsorbent. In order to measure the maximum adsorption capacity of the designed sorbent, $100 \mathrm{mg}$ of Alg-Mel sorbent was weighed and added into $40 \mathrm{~mL}$ of $\mathrm{Pb}^{2+}$-containing solution with concentrations ranging from 0.24 to $10.14 \mathrm{mM}$ for $6 \mathrm{~h}$. As shown in Figure 7, the adsorption capacity of Alg-Mel increases with the initial concentration from 0.24 to $4.34 \mathrm{mM}$, and then remains stable as the concentration increases further. Therefore, the maximum adsorption capacity for $\mathrm{Pb}^{2+}$ was calculated to be $1.39 \mathrm{mmol} / \mathrm{g}(287.7 \mathrm{mg} / \mathrm{g})$, which is much higher than that of most reported lead ion-sorbents (Table 2) [15-30]. 

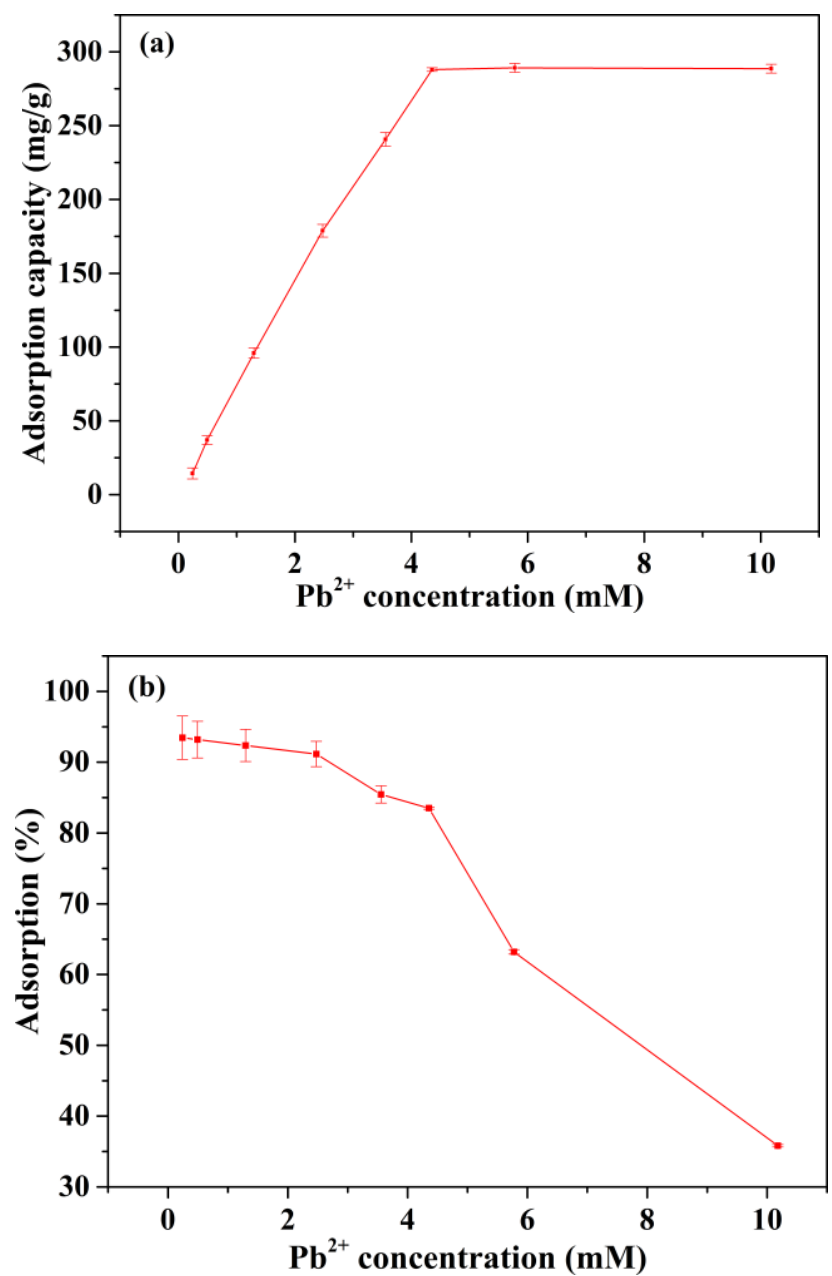

Figure 7. (a) Maximum adsorption capacity of $\mathrm{Alg}-\mathrm{Mel}$ for $\mathrm{Pb}^{2+},(\mathbf{b})$ adsorption efficiency of the Alg-Mel in different concentration of $\mathrm{Pb}^{2+}$ solution. ( 100 mg of Alg-Mel was equilibrated with $40 \mathrm{~mL}$ of $\mathrm{Pb}^{2+}$ solution at $25^{\circ} \mathrm{C}$ and $\mathrm{pH} 5.0$ for $6 \mathrm{~h}$ ).

Table 2. Comparison of the adsorption capacity of various sorbents towards $\mathrm{Pb}^{2+}$.

\begin{tabular}{cccc}
\hline Adsorbent & Target Heavy Metals & $\begin{array}{c}\text { Maximum Adsorption } \\
\text { Capacity }(\mathbf{m g} / \mathrm{g})\end{array}$ & Reference \\
\hline Alginate-melamine hybrid & $\mathrm{Pb}^{2+}$ & 287.7 & Our work \\
Polydopamine microspheres & $\mathrm{Pb}^{2+}$ & 165.8 & {$[15]$} \\
$\gamma-\mathrm{Fe}_{2} \mathrm{O}_{3}$ nanoparticles & $\mathrm{Cu}^{2+}, \mathrm{Pb}^{2+}$ & $34.0\left(\mathrm{Cu}^{2+}\right), 69.0\left(\mathrm{~Pb}^{2+}\right)$ & {$[16]$} \\
$\mathrm{Fe}_{3} \mathrm{O}_{4}$ nanoparticles & $\mathrm{Cr}^{6+}, \mathrm{Pb}^{2+}$ & $41.5\left(\mathrm{Cr}^{6+}\right), 96.8\left(\mathrm{~Pb}^{2+}\right)$ & {$[17]$} \\
imprinted $\mathrm{Pb}^{2+}$ & $\mathrm{Pb}^{2+}$ & 79.0 & {$[18]$} \\
Magnetic chitosan/graphene oxide & $\mathrm{Cd}^{2+}, \mathrm{Pb}^{2+}$ & $18.3\left(\mathrm{Cd}^{2+}\right), 57.7\left(\mathrm{~Pb}^{2+}\right)$ & {$[19]$} \\
Amino functionalized mesoporous silica & $\mathrm{Pb}^{2+}$ & 222.2 & {$[20]$} \\
Alginate-SBA-15 composite & $\mathrm{Pb}^{2+}$ & $51.5\left(\mathrm{~Pb}^{2+}\right)$ & {$[21]$} \\
Longan shell & $\mathrm{Pb}^{2+}$ & 18.9 & {$[22]$} \\
Silica modified calcium alginate-xanthan & & $120.8\left(\mathrm{Cd}^{2+}\right), 115.0$ & {$[23]$} \\
gum hybrid bead composite & $\mathrm{Cu}^{2+}, \mathrm{Pb}^{2+}$ & 263.2 & {$[24]$} \\
Soy protein hollow microspheres & $\left.\mathrm{Cd}^{2+}, \mathrm{Cu}^{2+}\right), 235.6\left(\mathrm{~Pb}^{2+}\right)$ & {$[25]$} \\
Biochar-alginate capsule & $\mathrm{Pb}^{2+}$ & 8.35 & {$[26]$} \\
$\mathrm{Pb}^{2+}$ ion imprinted polymers & $\mathrm{Pb}^{2+}$ & 15.7 & {$[27]$} \\
Activated carbon-calcium & $\mathrm{Pb}^{2+}$ & 50 & $\mathrm{~Pb}^{2+}$ \\
alginate composite & & & \\
Magnetic alginate beads & & &
\end{tabular}


Table 2. Cont.

\begin{tabular}{cccc}
\hline Adsorbent & Target Heavy Metals & $\begin{array}{c}\text { Maximum Adsorption } \\
\text { Capacity (mg/g) }\end{array}$ & Reference \\
\hline $\begin{array}{c}\text { Polyving alcohol/polyacrylic acid double } \\
\text { network gel }\end{array}$ & $\mathrm{Cd}^{2+}, \mathrm{Pb}^{2+}$ & $115.9\left(\mathrm{Cd}^{2+}\right), 195.0\left(\mathrm{~Pb}^{2+}\right)$ & {$[28]$} \\
Modified mesoporous $\mathrm{SiO}_{2}$ & $\mathrm{~Pb}^{2+}$ & 147.5 & {$[29]$} \\
Chitosan coated calcium alginate & $\mathrm{Pb}^{2+}$ & 106.9 & {$[30]$} \\
\hline
\end{tabular}

\subsection{Adsorption Mechanism}

To reveal the adsorption mechanism of the Alg-Mel, we also monitored the changes in $\mathrm{Ca}^{2+}$ and $\mathrm{Pb}^{2+}$ concentrations in the adsorption process. The ICP-OES analysis indicated that the concentration of $\mathrm{Ca}^{2+}$ increased with the reaction proceeded and the concentration of $\mathrm{Pb}^{2+}$ decreased gradually. However, after the adsorption, the mole mass of the adsorbed $\mathrm{Pb}^{2+}$ ions became greater than that of the desorbed $\mathrm{Ca}^{2+}$ ions, indicating that the ion exchange is not the only adsorption mechanism in the whole process. By combined with the $\mathrm{COO}^{-}$(carboxylate) peak of the Alg-Mel shifted after the $\mathrm{Pb}^{2+}$ adsorption (the carboxylate peak of the Alg-Mel shifted from 1329 to $1294 \mathrm{~cm}^{-1}$ ), which might be caused by the coordination of the carboxylate groups with the $\mathrm{Pb}^{2+}$. Thus, we proposed a possible adsorption mechanism as depicted in Figure 8.

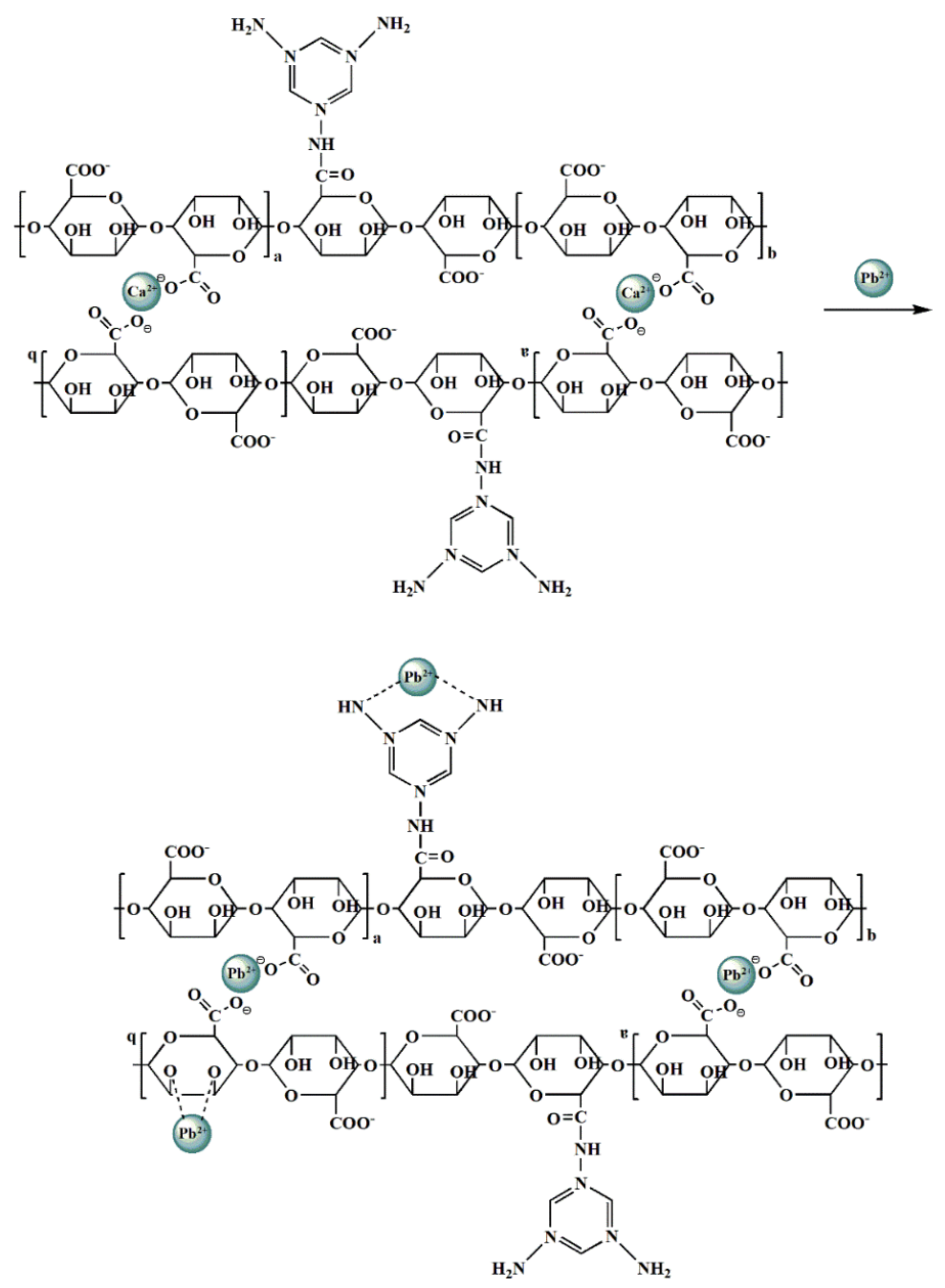

Figure 8. Possible binding mechanisms of Alg-Mel with $\mathrm{Pb}^{2+}$. 


\subsection{Reusability and Applications}

Different stripping agents such as $\mathrm{CH}_{3} \mathrm{COOH}, \mathrm{HNO}_{3}$ and $\mathrm{HCl}$ were used to desorb $\mathrm{Pb}^{2+}$ from the $\mathrm{Pb}^{2+}$-loaded Alg-Mel. It can be seen from Table 3 that $0.07 \mathrm{M} \mathrm{HNO}_{3}$ is more effective for desorbing $\mathrm{Pb}^{2+}$ from the $\mathrm{Pb}^{2+}$-loaded sorbent, in which more than $96 \%$ of adsorbed $\mathrm{Pb}^{2+}$ could be desorbed from the $\mathrm{Pb}^{2+}$-loaded Alg-Mel within a single wash. Therefore, $0.07 \mathrm{M}$ of $\mathrm{HNO}_{3}$ solution was selected as the stripping agent in this research.

Table 3. Effect of stripping agents on $\mathrm{Pb}^{2+}$ recovery ${ }^{1}$.

\begin{tabular}{ccc}
\hline Stripping Agent & Concentration (M) & $\mathbf{P b}^{\mathbf{2 +}}$ Recovery (\%) \\
\hline $\mathrm{CH}_{3} \mathrm{COOH}$ & 0.07 & 67.7 \\
$\mathrm{CH}_{3} \mathrm{COOH}$ & 0.02 & 32.8 \\
$\mathrm{HCl}$ & 0.07 & 93.5 \\
$\mathrm{HCl}$ & 0.02 & 81.0 \\
$\mathrm{HNO}_{3}$ & 0.07 & 96.3 \\
$\mathrm{HNO}_{3}$ & 0.02 & 85.7 \\
\hline & 100 mg of Alg-Mel and $40 \mathrm{~mL}$ of stripping agent were used in each desorption test.
\end{tabular}

In order to evaluate the recyclability of the sorbent, the same Alg-Mel sorbent was used to uptake $\mathrm{Pb}^{2+}$ through ten adsorbing-desorbing cycles. As shown in Figure 9, the adsorption ability of the Alg-Mel remains stable in ten cycles. It can remove $93 \% \pm 3 \%$ of $\mathrm{Pb}^{2+}$ from the $\mathrm{Pb}^{2+}$-containing solution, and its shape does not change much after recycling (Figure 10). These finding indicates that the as-prepared Alg-Mel sorbent possesses high chemical and mechanical stability as well as high recyclability.

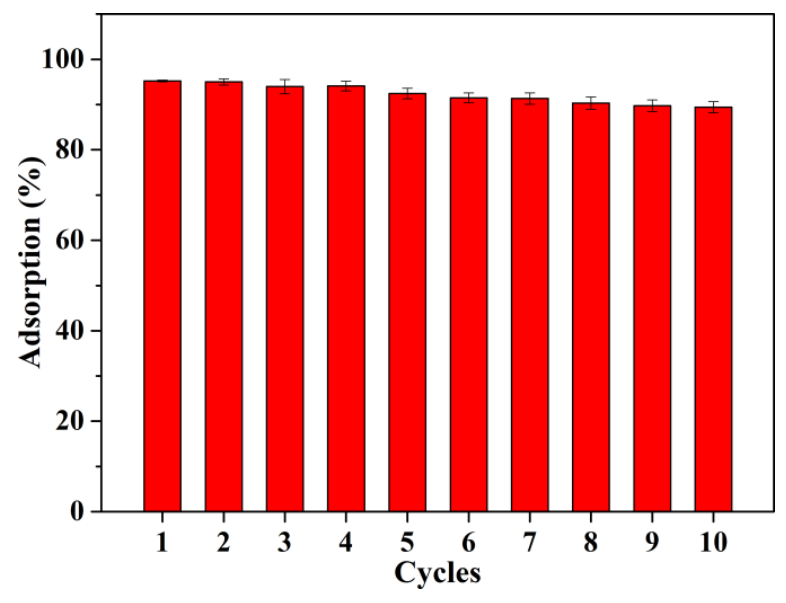

Figure 9. Adsorption ability of the Alg-Mel in ten adsorbing-desorbing cycles.
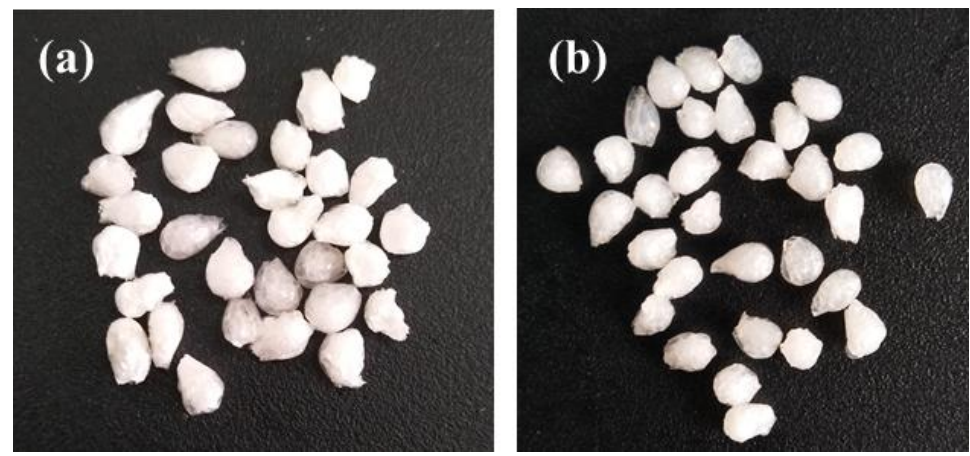

Figure 10. Images of the Alg-Mel (a) before adsorption and (b) after recycling ten times. 


\section{Conclusions}

In this work, a highly efficient alginate-melamine hybrid sorbent (Alg-Mel) was designed and fabricated for removing $\mathrm{Pb}^{2+}$ from $\mathrm{Pb}^{2+}$-containing wastewater. The as-prepared Alg-Mel exhibited high affinity and selectivity towards $\mathrm{Pb}^{2+}$, it could adsorb $95.4 \%$ of $\mathrm{Pb}^{2+}$ in aqueous solution, and the maximum adsorption capacity for $\mathrm{Pb}^{2+}$ reached $287.7 \mathrm{mg} / \mathrm{g}$, which is much higher than that of most reported lead ion-sorbents. Moreover, the application results in natural water samples are also satisfactory. The results of adsorption mechanism analysis indicated that Alg-Mel adsorb the heavy metals mainly by the chemical coordination and ion exchange effects. The low-cost raw materials, simple synthesis process, efficient adsorption ability and high recyclability mean that the synthetic Alg-Mel sorbent has great potential in the treatment of $\mathrm{Pb}^{2+}$-containing wastewater.

Author Contributions: Z.W. conceived and designed the experiments; K.L. performed the experiments; K.L. and X.Z. analyzed the data; Z.W. and M.W. wrote the paper; G.W. and Z.W. made revisions of the manuscript.

Funding: This research was funded by the national natural science foundation of China grant number [No.21407004] and natural science foundation of Anhui province grant number [Nos.1508085QB48, KJ2017A345].

Conflicts of Interest: The authors declare no conflict of interest.

\section{References}

1. Zhang, C.; Zhou, Y.Y.; Tang, L.; Zeng, G.M.; Zhang, J.C.; Peng, B.; Xie, X.; Lai, C.; Long, B.Q.; Zhu, J.J. Determination of $\mathrm{Cd}^{2+}$ and $\mathrm{Pb}^{2+}$ based on mesoporous carbon nitride/self-doped polyaniline nanofibers and square wave anodic stripping voltammetry. Nanomaterials 2016, 6, 7. [CrossRef] [PubMed]

2. Magri, D.; Caputo, G.; Perotto, G.; Scarpellini, A.; Colusso, E.; Drago, F.; Martucci, A.; Athanassiou, A.; Fragouli, D. Titanate fibroin nanocomposites: A novel approach for the removal of heavy-metal ions from water. ACS Appl. Mater. Interfaces 2018, 10, 651-659. [CrossRef] [PubMed]

3. Wang, Z.Q.; Wu, A.G.; Ciacchi, L.C.; Wei, G. Recent advances in nanoporous membranes for water purification. Nanomaterials 2018, 8, 65. [CrossRef] [PubMed]

4. Zou, Y.D.; Wang, X.X.; Khan, A.; Wang, P.Y.; Liu, Y.H.; Alsaedi, A.; Hayat, T.; Wang, X.K. Environmental remediation and application of nanoscale zero-valent iron and its composites for the removal of heavy metal ions: A review. Environ. Sci. Technol. 2016, 50, 7290-7304. [CrossRef] [PubMed]

5. Wang, Z.Q.; Ciacchi, L.C.; Wei, G. Recent advances in the synthesis of graphene-based nanomaterials for controlled drug delivery. Appl. Sci. 2017, 7, 1175. [CrossRef]

6. Ciosek, A.L.; Luk, G.K. An innovative dual-column system for heavy metallic ion sorption by natural zeolite. Appl. Sci. 2017, 7, 795. [CrossRef]

7. Uddin, M.K. A review on the adsorption of heavy metals by clay minerals, with special focus on the past decade. Chem. Eng. J. 2017, 308, 438-462. [CrossRef]

8. Dash, S.; Chaudhuri, H.; Gupta, R.; Nair, U.G.; Sarkar, A. Fabrication and application of low-cost thiol functionalized coal fly ash for selective adsorption of heavy toxic metal ions from water. Ind. Eng. Chem. Res. 2017, 56, 1461-1470. [CrossRef]

9. Wang, Z.Q.; Huang, Y.G.; Wang, M.; Wu, G.H.; Geng, T.M.; Zhao, Y.G.; Wu, A.G. Macroporous calcium alginate aerogel as sorbent for $\mathrm{Pb}^{2+}$ removal from water media. J. Environ. Chem. Eng. 2016, 4, 3185-3192. [CrossRef]

10. Wang, Z.Q.; Wu, D.Y.; Wu, G.H.; Yang, N.N.; Wu, A.G. Modifying $\mathrm{Fe}_{3} \mathrm{O}_{4}$ microspheres with rhodamine hydrazide for selective detection and removal of $\mathrm{Hg}^{2+}$ ion in water. J. Hazard. Mater. 2013, 244, 621-627. [CrossRef] [PubMed]

11. Ziaei, E.; Mehdinia, A.; Jabbari, A. A novel hierarchical nanobiocomposite of graphene oxide-magnetic chitosan grafted with mercapto as a solid phase extraction sorbent for the determination of mercury ions in environmental water samples. Anal. Chim. Acta 2014, 850, 49-56. [CrossRef] [PubMed]

12. Papageorgiou, S.K.; Kouvelos, E.P.; Favvas, E.P.; Sapalidis, A.A.; Romanos, G.E.; Katsaros, F.K. Metal-carboxylate interactions in metal-alginate complexes studied with FTIR spectroscopy. Carbohyd. Res. 2010, 345, 469-473. [CrossRef] [PubMed] 
13. Lim, S.F.; Zheng, Y.M.; Zou, S.W.; Chen, J.P. Characterization of copper adsorption onto an alginate encapsulated magnetic sorbent by a combined FT-IR, XPS and mathematical modeling study. Environ. Sci. Technol. 2008, 42, 2551-2556. [CrossRef] [PubMed]

14. Kokkinos, E.; Soukakos, K.; Kostoglou, M.; Mitrakas, M. Cadmium, mercury, and nickel adsorption by tetravalent manganese feroxyhyte: Selectivity, kinetic modeling, and thermodynamic study. Environ. Sci. Pollut. R. 2018, 25, 12263-12273. [CrossRef] [PubMed]

15. Zhang, Q.R.; Yang, Q.G.; Phanlavong, P.; Li, Y.X.; Wang, Z.K.; Jiao, T.F.; Peng, Q.M. Highly efficient lead(II) sequestration using size-controllable polydopamine microspheres with superior application capability and rapid capture. ACS Sustain. Chem. Eng. 2017, 5, 4161-4170. [CrossRef]

16. Rajput, S.; Singh, L.P.; Pittman, C.U.; Mohan, D. Lead $\left(\mathrm{Pb}^{2+}\right)$ and copper $\left(\mathrm{Cu}^{2+}\right)$ remediation from water using superparamagnetic maghemite $\left(\gamma-\mathrm{Fe}_{2} \mathrm{O}_{3}\right)$ nanoparticles synthesized by flame spray pyrolysis (FSP). J. Colloid Interface Sci. 2017, 492, 176-190. [CrossRef] [PubMed]

17. Wang, L.X.; Li, J.C.; Jiang, Q.; Zhao, L.J. Water-soluble $\mathrm{Fe}_{3} \mathrm{O}_{4}$ nanoparticles with high solubility for removal of heavy-metal ions from waste water. Dalton Trans. 2012, 41, 4544-4551. [CrossRef] [PubMed]

18. Lei, Y.; Guan, J.J.; Chen, W.; Ke, Q.F.; Zhang, C.Q.; Guo, Y.P. Fabrication of hydroxyapatite/chitosan porous materials for $\mathrm{Pb}(\mathrm{II})$ removal from aqueous solution. RSC Adv. 2015, 5, 25462-25470. [CrossRef]

19. Heidari, A.; Younesi, H.; Mehraban, Z. Removal of $\mathrm{Ni}(\mathrm{II}), \mathrm{Cd}(\mathrm{II})$, and $\mathrm{Pb}(\mathrm{II})$ from a ternary aqueous solution by amino functionalized mesoporous and nano mesoporous silica. Chem. Eng. J. 2009, 153, 70-79. [CrossRef]

20. Cheraghali, R.; Tavakoli, H.; Sepehrian, H. Preparation, characterization and lead sorption performance of alginate-SBA-15 composite as a novel adsorbent. Sci. Iran. 2013, 20, 1028-1034.

21. Huang, M.R.; Li, S.; Li, X.G. Longan shell as novel biomacromolecular sorbent for highly selective removal of lead and mercury ions. J. Phys. Chem. B 2010, 114, 3534-3542. [CrossRef] [PubMed]

22. Zhang, S.; Xu, F.; Wang, Y.F.; Zhang, W.Z.; Peng, X.L.; Pepe, F. Silica modified calcium alginate-xanthan gum hybrid bead composites for the removal and recovery of $\mathrm{Pb}$ (II) from aqueous solution. Chem. Eng. J. 2013, 234, 33-42. [CrossRef]

23. Liu, D.G.; Li, Z.H.; Li, W.; Zhong, Z.R.; Xu, J.Q.; Ren, J.J.; Ma, Z.S. Adsorption behavior of heavy metal ions from aqueous solution by soy protein hollow microspheres. Ind. Eng. Chem. Res. 2013, 52, 11036-11044. [CrossRef]

24. Do, X.H.; Lee, B.K. Removal of $\mathrm{Pb}^{2+}$ using a biochar-alginate capsule in aqueous solution and capsule regeneration. J. Environ. Manag. 2013, 131, 375-382. [CrossRef] [PubMed]

25. Cai, X.Q.; Li, J.H.; Zhang, Z.; Yang, F.F.; Dong, R.C.; Chen, L.X. Novel $\mathrm{Pb}^{2+}$ ion imprinted polymers based on ionic interaction via synergy of dual functional monomers for selective solid-phase extraction of $\mathrm{Pb}^{2+}$ in water samples. ACS Appl. Mater. Interfaces 2014, 6, 305-313. [CrossRef] [PubMed]

26. Cataldo, S.; Gianguzza, A.; Milea, D.; Muratore, N.; Pettignano, A. Pb(II) adsorption by a novel activated carbon-alginate composite material. A kinetic and equilibrium study. Int. J. Biol. Macromol. 2016, 92, 769-778. [CrossRef] [PubMed]

27. Idris, A.; Ismail, N.S.M.; Hassan, N.; Misran, E.; Ngomsik, A.F. Synthesis of magnetic alginate beads based on maghemite nanoparticles for $\mathrm{Pb}$ (II) removal in aqueous solution. J. Ind. Eng. Chem. 2012, 18, 1582-1589. [CrossRef]

28. Chu, L.; Liu, C.B.; Zhou, G.Y.; Xu, R.; Tang, Y.H.; Zeng, Z.B.; Luo, S.L. A double network gel as low cost and easy recycle adsorbent: Highly efficient removal of $\mathrm{Cd}(\mathrm{II})$ and $\mathrm{Pb}(\mathrm{II})$ pollutants from wastewater. J. Hazard. Mater. 2015, 300, 153-160. [CrossRef] [PubMed]

29. Liu, Y.; Lou, Z.M.; Sun, Y.; Zhou, X.X.; Baig, S.A.; Xu, X.H. Influence of complexing agent on the removal of $\mathrm{Pb}(\mathrm{II})$ from aqueous solutions by modified mesoporous $\mathrm{SiO}_{2}$. Micropor. Mesopor. Mater. 2017, 246, 1-13. [CrossRef]

30. Mousa, N.E.; Simonescu, C.M.; Patescu, R.E.; Onose, C.; Tardei, C.; Culita, D.C.; Oprea, O.; Patroi, D.; Lavric, $\mathrm{V} . \mathrm{Pb}^{2+}$ removal from aqueous synthetic solutions by calcium alginate and chitosan coated calcium alginate. React. Funct. Polym. 2016, 109, 137-150. [CrossRef]

(C) 2018 by the authors. Licensee MDPI, Basel, Switzerland. This article is an open access article distributed under the terms and conditions of the Creative Commons Attribution (CC BY) license (http:/ / creativecommons.org/licenses/by/4.0/). 